\title{
NUTRITIONAL AND PHENOLIC PROFILE OF SMALL EDIBLE FUNGAL SPECIES COPRINELLUS DISSEMINATUS (PERS.) J.E. LANGE 1938
}

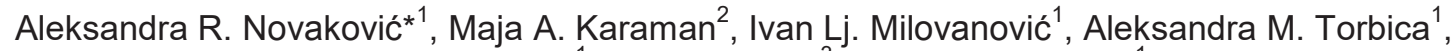 \\ Jelena M. Tomić ${ }^{\text {, B Boris M. Pejin }}{ }^{3}$, Marijana B. Sakać ${ }^{1}$ \\ ${ }^{1}$ University of Novi Sad, Institute of Food Technology, 21000 Novi Sad, Bulevar cara Lazara 1, Serbia \\ ${ }^{2}$ University of Novi Sad, Department of Biology and Ecology, Faculty of Sciences, 21000 Novi Sad, \\ Trg Dositeja Obradovića 2, Serbia \\ ${ }^{3}$ University of Belgrade, Department of Life Sciences, Institute for Multidisciplinary Research (IMSI), \\ 11030 Belgrade, Kneza Višeslava 1, Serbia
}

\author{
*Corresponding author: \\ Phone: +381214853770 \\ Fax: +38121450725 \\ E-mail address: aleksandra.novakovic@fins.uns.ac.rs
}

\begin{abstract}
The aim of this work was to investigate nutritional profile in relation to proteins, amino acids, fatty acids and mineral composition, as well as phenolic profile of small edible fungal species Coprinellus disseminatus originated from Serbia. Total protein content in the analyzed fungal species was $9.72 \%$. Fifteen protein fractions obtained by electrophoresis were identified in a range from 1.6 to $63.6 \mathrm{kDa}$. Chip-based separations showed the presence of protein fraction with molecular weight of $27.5 \mathrm{kDa}$ that could possess antifungal activity. The total essential and non-essential amino acid contents were 29.57 and $96.69 \mathrm{mg} / \mathrm{g}$ DW, respectively. Among the essential amino acids, leucine was the most abundant. Fatty acid composition of $C$. disseminatus showed that polyunsaturated fatty acids (PUFA, 59.1\% of total FA) predominated over saturated fatty acids (SFA, $23.1 \%$ of total FA) and monounsaturated fatty acids (MUFA, $17.9 \%$ of total FA). The dominant fatty acids were linoleic acid $(56.6 \%)$, palmitic acid (13.9\%), and oleic acid (12.0\%). The most abundant macroelement in $C$. disseminatus was potassium, followed by calcium and magnesium, while iron dominated in microelements. Eight phenolic compounds were quantified in methanolic extract of $C$. disseminatus by LC-MS/MS with the highest amount of $p$-hydroxybenzoic acid and p-coumaric acid reaching $9.46 \pm$ $0.2 \mu \mathrm{g} / \mathrm{g}$ DW and $7.8 \pm 0.1 \mu \mathrm{g} / \mathrm{g} \mathrm{DW}$, respectively.
\end{abstract}

Key words: mushroom, proteins, amino acids, fatty acid profile, phenolic profile, mineral composition

\section{INTRODUCTION}

Since earliest times mushrooms have been priced as a special kind of food, while during recent years they have become more attractive as functional food due to their proved medicinal values. They are valuable sources of physiologically beneficial compounds which provide their therapeutic effect and enable their usage as dietary supplements (Ferreira et al., 2009; Novaković et al., 2015). Mushrooms actually are mycofactories as they produce variety of secondary metabolites, including phenolic compounds, polyketides, terpenes and steroids (Turkoglu et al., 2007). Numerous bioactive properties of mushrooms, such as antioxidant, antitumor (Ferreira et al., 2010; Puttaraju et al., 2006; Vaz et al., 2012; Wasser, 2002; Zaidman et al., 2005), and antimicrobial activities (Barros et al., 2007, Karaman et al., 2009; Karaman et al., 2012; Stojković et al., 2013) were discovered and addressed to abovementioned compounds. It is assumed that the presence of these com- 
pounds provides protection against certain chronic diseases such as cardiovascular diseases, cancer, diabetes, and neurological disorders (Zhou et al., 2009). It should be noted that the composition of mushrooms is affected by the diversity of their genetic makeup that is expressed by strains differences as well as by environmental conditions, including the nature of substratum they grow on (Miles and Chang, 2004).

Due to the possible application of edible mushrooms in the treatment and prevention of many diseases of modern life they have been thoroughly analyzed as therapeutic alternatives (Kalogeropoulos et al., 2013; Karaman et al., 2014; Zaidman et al., 2005). Their nutritional value is also of great interest as they can be used as ingredients in food formulations (Leal et al., 2013; Ribeiro et al., 2009).

The usage of mushrooms implies some advantages. Namely, the fruiting body can be produced in a short period of time, and the mycelium may also be rapidly produced in liquid culture and the culture medium can be manipulated to produce optimal quantities of active compounds (Elisashvili, 2012).

Coprinellus disseminatus (Pers.) J.E. Lange 1938 is a mushroom (phylum Basidiomycota, fam. Psathyrellaceae) whose different extracts (ethanolic, dichloromethane, ethanolic and aqueous extracts) were examined and evidenced to possess antioxidant (Han et al., 1999), antibacterial (Gu and Leonard, 2006) and antiproliferative activity (Novaković et al., 2016). Despite its small size, discovered bioactive properties of $C$. disseminatus may refer to its biotechnological exploitation, but there is an absence of its nutritional profile which can be useful in food creation. Therefore, the aim of this paper was to evaluate nutritional profile (proteins, amino acid composition, fatty acid profile, and mineral composition) of fungal species $C$. disseminatus originated from Serbia as well as its phenolic profile.

\section{MATERIALS AND METHODS}

\section{Standards and reagents}

Reference standards of the phenolic compounds were obtained from Sigma-Aldrich
Chem (Steinheim, Germany), Fluka Chemie $\mathrm{GmbH}$ (Buchs, Switzerland) and from Chromadex (Santa Ana, USA). HPLC gradient grade methanol was purchased from J. T. Baker (Deventer, The Netherlands) and p.a. grade formic acid was obtained from Merck (Darmstadt, Germany). The fatty acids methyl ester (FAME) reference standard mixture 37 (Supelco) was purchased from Sigma (Sigma-Aldrich, EU). Deionized water was produced using a Millipore water purification system (Darmstadt, Germany). All other chemicals and solvents were of analytical grade.

\section{Mushroom samples}

The species C. disseminatus (Pers.) 1938 was collected from an urban location of Novi Sad (Serbia) during 2012. Identification of the species was based on classical determination while voucher specimen (12-00662) was deposited at the mycological collection of the Herbarium BUNS (Faculty of Sciences, Department of Biology and Ecology, University of Novi Sad, Serbia). The samples were frozen at $-20{ }^{\circ} \mathrm{C}$ and lyophilized during $48 \mathrm{~h}$ (BioAlpha, Martin Christ $\mathrm{GmbH}$, Switzerland). Lyophilized samples were ground to a fine powder, packed in sealed plastic tubes and stored in a dark place at room temperature $\left(23 \pm 1{ }^{\circ} \mathrm{C}\right)$ prior to analysis.

\section{Extraction with methanol}

The entire lyophilized and powdered fruiting bodies of $C$. disseminatus $(10 \mathrm{~g}$ ) were extracted with $100 \mathrm{~mL}$ of methanol using a shaker (Thermofisher Scientific, USA) at $120 \mathrm{rpm}$ for $24 \mathrm{~h}$ at room temperature (23 $\pm 1{ }^{\circ} \mathrm{C}$ ). The extract was filtered through Whatman No. 4 filter paper and the solvent was removed by vacuum-evaporator at $40{ }^{\circ} \mathrm{C}$ (Büchi, Switzerland). The obtained extract was stored at $-20{ }^{\circ} \mathrm{C}$ prior to phenolic profile analysis.

\section{Protein content}

The crude protein content $\mathrm{N} 4.38$ of the samples was estimated by the macroKjeldahl method using the standard procedure (AOAC, 1995).

\section{Determination of protein profile}

Sample preparation was carried out according to Tidona et al. (2011) with some 
modifications. The lyophilized and powdered fruiting bodies of $C$. disseminatus (15 $\mathrm{mg})$ were dissolved in $100 \mu \mathrm{L}$ buffer $(0.125$ $\mathrm{M}$ Tris $\mathrm{HCl}, 4 \%$ SDS, $2 \%$ glycerol, $2 \% \beta-$ mercaptoethanol, $\mathrm{pH}$ 6.8) and heated at $100{ }^{\circ} \mathrm{C}$ for $5 \mathrm{~min}$. The chip-based separations were performed on an Agilent 2100 Bioanalyzer (Agilent Technologies, Santa Clara, CA, USA) in combination with the Protein 80 Plus LabChip kit and the dedicated Protein 80 software assay on 2100 expert software. Chips were prepared according to the protocol provided by the Protein 80 LabChip kit. Fractioning is sizebased, and the profiles show the smallest proteins emerging first in the profiles but at the bottom of the gel patterns, according to the convention for SDS-PAGE (Torbica et al., 2010). Bovine serum albumin was used as the standard for quantitation of the fungi proteins. All samples were analyzed in triplicate.

\section{Determination of amino acid composition}

Fungal samples were subjected to acid hydrolysis to determine the amino acid composition according to the modified method by Fountoulakis and Lahm (1998). The lyophilized samples (50 mg) were hydrolyzed by hydrochloric acid solution (6 M $\mathrm{HCl}$ containing $0.1 \%$ phenol and $3 \%$ thioglycolic acid, v/v) for $24 \mathrm{~h}$, and the hydrolysis was done in sealed vessels under nitrogen atmosphere.

The amino acid composition of the samples was determined by high performance liquid chromatography (HPLC) on the HPLC Agilent 1200 Series instrument (Agilent Technologies, Palo Alto, USA) using Agilent Eclipse Plus C18 $(5.0 \mu \mathrm{m}, 3.0 \mathrm{x}$ $250 \mathrm{~mm}$ ) column. For peak detection, a fluorescence detector (FLD) was used, with excitation parameters at $340 \mathrm{~nm}$ and emission at $450 \mathrm{~nm}$. Since previous derivatization is required for the analysis of amino acids under these conditions, this was achieved by pre-column derivatization of hydrolysates with ortho-phthalaldehyde (OPA) and 9-fluorenylmethyl chloroformate (FMOC). The pre-column derivatization and chromatographic analysis of amino acids was carried out according to Agilent Technologies application note No.
5990-4547EN (Henderson and Brooks, 2010), detailing the parameters and conditions of the chromatographic separation, the derivatization procedure with the ready reagent sets and the method of preparing the amino acid calibration standards.

A mixture of the amino acid standards used for calibration was prepared by diluting standard mixtures with $0.1 \mathrm{M} \mathrm{HCl}$, and a dilution series in the range of 0.1-2 $\mu \mathrm{mol} / \mathrm{mL}$ was obtained. The calibration curve was constructed for each individual amino acid, based on the obtained peak areas depending on the concentration of the standard (the linear coefficients for the individual calibration curves were in the range $\mathrm{R}=0.9956-0.9993)$. The calculated values for each individual amino acid were corrected for the calculated value of the analytical yield (analytical yield values were from $67.2 \%$ for tryptophan, up to $106.7 \%$ for glycine). From the obtained linear dependence equation, the concentrations of individual amino acids in the samples were calculated and expressed as $\mathrm{mg} / \mathrm{g}$ of the sample.

\section{Fatty acid profile}

To establish a fatty acid profile, samples were firstly subjected to extraction by the method of Folch (Folch et al., 1957). Extracted lipids were then submitted to trans-esterification using $14 \%$ boron(III)fluoride in methanol (Ackman, 1998) to obtain fatty acid methyl esters (FAMEs). Samples were then analyzed by a GC Agilent 7890A system. System was equipped with flame-ionization detector (FID) and with fused silica capillary column (Supelco SP-2560, $100 \mathrm{~m}, 0.25 \mathrm{~mm}, 0.20$ $\mu \mathrm{m}$ ). A carrier gas was helium (purity $>$ 99.9997 vol \%, flow rate was 1.00 $\mathrm{mL} / \mathrm{min})$. Two $\mu \mathrm{L}$ of sample were injected in split mode (25:1), with following oven temperature conditions: $140{ }^{\circ} \mathrm{C}$ for $5 \mathrm{mi}-$ nutes followed by temperature ramp of $3{ }^{\circ} \mathrm{C} / \mathrm{min}$ to $240{ }^{\circ} \mathrm{C}$ and held for $10 \mathrm{mi}-$ nutes.

Identification of fatty acids in samples was done by comparison of their retention times with retention times of mixture with 37 standards (Supelco) and with data from internal data library. Final results were 
shown as gram of fatty acid or fatty acid group (g) per $100 \mathrm{~g}$ of total fatty acids.

\section{Macro- and microelements analysis}

Determination of selected macro- $(\mathrm{K}, \mathrm{Ca}$ and $\mathrm{Mg}$ ) and microelements $(\mathrm{Cu}, \mathrm{Mn}, \mathrm{Fe}$ and $\mathrm{Zn}$ ) in lyophilized and powdered sample of $C$. disseminatus was done using flame atomic absorption spectroscopy (AAS). Approximately $0.3 \mathrm{~g}$ of oven-dried $\left(70{ }^{\circ} \mathrm{C}\right.$ for $24 \mathrm{~h}$ ) material was ground and homogenized in a laboratory mill and then digested in $10 \mathrm{~mL}$ of nitric acid and $2 \mathrm{~mL}$ of $30 \%(\mathrm{w} / \mathrm{v})$ hydrogen peroxide using a microwave-assisted digestion system (D series, Milestone, Bergamo, Italy) at $180^{\circ} \mathrm{C}$ for 45 min with microwave power of $900 \mathrm{~W}$. Digested samples were diluted to $25 \mathrm{~mL}$ with deionized water. Pre-treated samples were processed by atomic absorption spectrophotometer (FS AAS240/GTA120, Varian) using the acetylene/air burner flame technique (with an atomization temperature of about $2300^{\circ} \mathrm{C}$ ) for $\mathrm{Cu}$ and $\mathrm{Mg}$ quantification, while a nitrous oxide $\left(\mathrm{N}_{2} \mathrm{O}\right)$-acetylene flame (with a temperature of about $2700{ }^{\circ} \mathrm{C}$ ) was used for $\mathrm{Ca}$ content determination. By using single element hollow-cathode lamps concentrations of $\mathrm{Cu}, \mathrm{Mg}$ and $\mathrm{Ca}$ were determined at 324.8, 285.2 and $422.7 \mathrm{~nm}$, respectively and expressed as $\mathrm{mg} / \mathrm{kg}$ or $\mu \mathrm{g} / \mathrm{kg}$ of dry weight of fungi material.

\section{Phenolic compounds profile}

Analysis of phenolic profile was done according to method described by Orčić et al. (2014). For separation of the phenolic compounds Agilent 1200 series HPLCMS/MS chromatograph was employed equipped with reversed-phase column Zorbax Eclipse XDB-C18 4.6 mm x 50 mm $x 1.8 \mathrm{~mm}$ (Agilent Technologies) that was held at $40{ }^{\circ} \mathrm{C}$. Detection of analytes was done by Agilent series 6410A triple-quadrupole mass spectrometer using electrospray ionization (ESI). For instrument control and data analysis, MassHunter ver. B.03.01. software (Agilent Technologies) was used. Mobile phase used in analysis was made of $0.05 \%$ formic acid $(A)$ and methanol $(B)$ with a flow rate of $1 \mathrm{~mL} / \mathrm{min}$ and solvent gradient: start with $70 \% \mathrm{~A} /$ $30 \% \mathrm{~B}$, attaining $30 \% \mathrm{~A} / 70 \% \mathrm{~B}$ in 6.00 min, following $100 \% \mathrm{~B}$ at $9.00 \mathrm{~min}$, held until $12.00 \mathrm{~min}$, and then with $3 \mathrm{~min}$ to reequilibrate. Sample injection volume was 5 $\mu \mathrm{L}$. ESI has been done under following conditions: drying gas $\left(\mathrm{N}_{2}\right)$ temperature $350{ }^{\circ} \mathrm{C}$; flow $9 \mathrm{~L} / \mathrm{min}$; nebulizer gas pressure $40 \mathrm{psi}$; capillary voltage $4 \mathrm{kV}$, negative polarity.

Dynamic MRM (multiple reaction monitoring) mode was used for quantification of all compounds. For analysis a mix of stock standard solutions was used. Starting concentration of each compound was 100 $\mu \mathrm{g} / \mathrm{mL}$ which was subsequently serially diluted (in methanol-water; 1:1). This resulted in working standard solutions with concentration range from $0.0015 \mu \mathrm{g} / \mathrm{mL}$ to $25.0 \mu \mathrm{g} / \mathrm{mL}$. These standard solutions were used for construction of the calibration curves. Quantification of individual peaks (compounds) was done by using the equation for linear regression resulting from the calibration curves $\left(R^{2}=0.995\right)$.

\section{RESULTS AND DISCUSSION}

\section{Protein profile}

The nutritional value of mushrooms is primarily related to their high quality protein content. It is not only dependent on environmental factors or stage of the fruiting body maturity, but also on the genotype specificity of the species (Wang et al., 2014). On a dry weight basis, mushrooms normally contain $19-35 \%$ of proteins (Miles and Chang, 2004).

Total protein content in analyzed fungal species was $9.72 \%$, being in accordance with the previously detected content (11.00-11.24\%) in C. comatus (Redhead et al., 2001).

Mushroom proteins are characterized by various biological activities such as antitumor, antiviral, antimicrobial, antioxidative, and immunomodulatory activity (Xu et al., 2011). Various pharmaceutical properties of mushroom proteins lead to the growing tendency in protein engineering focused on the protein specific activities (Ivanova et al., 2014).

C. disseminatus protein characterization obtained by electrophoresis identified 15 protein fractions and their molecular weights were in the range from 1.6 to 63.6 $\mathrm{kDa}$. Results of the chip-based separation 
showed the presence of protein fraction with molecular weight of $27.5 \mathrm{kDa}$ (Fig. 1). According to Ngai and $\mathrm{Ng}$ (2003) the lentin, protein derived from shitake mushroom with a molecular mass of $27.5 \mathrm{kDa}$, inhibited mycelial growth in a variety of fungal species. The mentioned authors noted that it also exerted an inhibitory activity on HIV-1 reverse transcriptase and proliferation of leukemic cells.

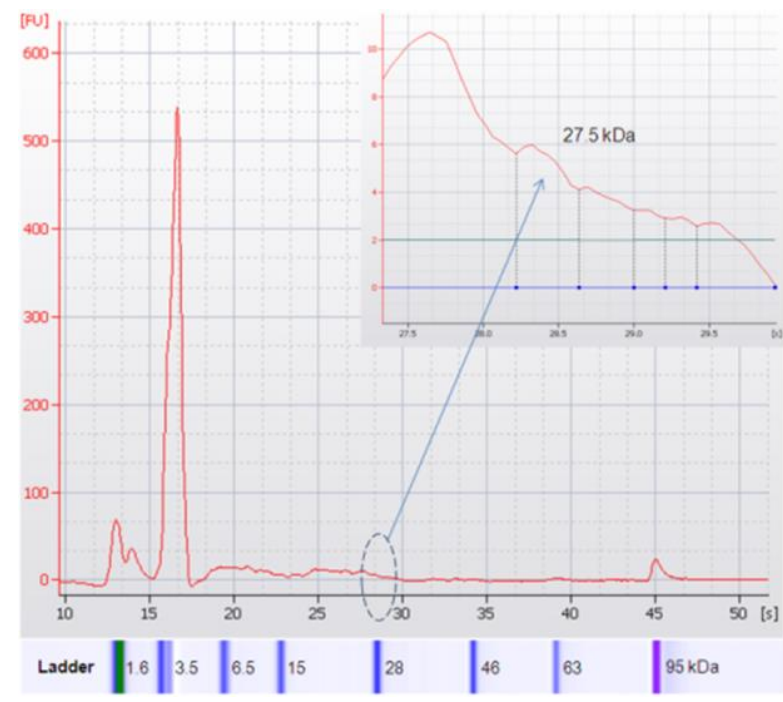

Figure 1. Electropherogram of $C$. disseminatus protein fraction with molecular weight of $27.5 \mathrm{kDa}$

The proteins of commonly cultivated mushrooms contain all nine essential amino acids (EAA) for humans - lysine, methionine, tryptophan, threonine, valine, leucine, isoleucine, histidine and phenylalanine, among which the most abundant is lysine and the lowest levels are those of tryptophan and methionine (Miles and Chang, 2004). Amino acid composition of C. disseminatus is presented in Table 1, showing that analyzed species was especially rich in arginine, alanine, cystein and glutamic acid. Among the essential amino acids, leucine was more abundant than valine and threonine. The total essential and non-essential amino acid contents were 29.57 and $96.69 \mathrm{mg} / \mathrm{g} \mathrm{DW}$, respectively. In a previous study done by Ayaz et al. (2011) mushrooms from the East Black Sea region contained a high amount of glutamic acid, while leucine was the most abundant among EAA, which is being in line with the obtained results.

Arginine is a precursor of nitric oxide, be- ing important in people with angina and congestive heart failure (Appleton, 2002). It also acts by stimulating immune function and promoting the secretion of several hormones, such as glucagon, insulin and growth hormone (Meletis and Barker, 2005). Arginine is a semi-essential amino acid for humans, also is of great importance in babies, as they cannot produce it in their first months. In adults it becomes more important when body is submitted to a great physical stress, when additional arginine is required in a regular diet (Belitz and Grosch, 1999).

\section{Fatty acid profile}

Edible mushrooms are considered a good source of many different nutraceuticals such as unsaturated fatty acids (Yilmaz et. al., 2006) and C. disseminatus is not an exception. Fatty acid composition of $C$. disseminatus (Table 2) showed that polyunsaturated fatty acids (PUFA, 59.1\% of total FA) predominated over saturated fatty acids (SFA, $23.1 \%$ of total FA) and monounsaturated fatty acids (MUFA, $17.9 \%$ of total FA). Among PUFA, the main was linoleic acid $(56.6 \%)$, which was followed by SFA palmitic acid (13.9\%), and MUFA oleic acid (12.0\%).

The determined fatty acid profile of $C$. disseminatus was consistent with previously published data for $C$. comatus from Serbia (Stojković et al., 2013), Portugal (Vaz et al., 2011) and Turkey (Yilmaz et al., 2006). There is extensive scientific evidence showing that dietary PUFA may protect against several conditions such as cardiovascular, psychiatric, neurological, dermatological and rheumatologic disorders (Rubio-Rodríguez et al., 2010). Beside many phenolic compounds, especially low-molecular-weight phenolic compounds that were identified to possesses antimicrobial properties (Karaman et al., 2009, Karaman et al., 2012; Karaman et al., 2014; Novaković et al., 2016), mushroom fatty acids, especially palmitic acid from $G$. applanatum fruiting bodies and Dictyophora echino-volvatus, showed strong antimicrobial activity against gramnegative bacteria (Moradali et al., 2008) as well as against many microorganisms (S. aureus, E. coli, S. cerevisiae, C. albicans, Penicillium citrinum and $A$ niger) 
(Shen et al., 2017). These facts indicate the possible potential of $C$. disseminates interms of antimicrobial activity because it possessed relatively high content of palmitic acid.

Table 1.

Amino acid composition of $C$. disseminates $(\mathrm{mg} / \mathrm{g} \mathrm{DW}$ )

\begin{tabular}{|c|c|c|c|c|c|c|c|c|}
\hline Val & Met & Phe & Ile & Leu & Lys & Thr & \multicolumn{2}{|c|}{ His } \\
\hline $5.61 \pm 0.22$ & $1.83 \pm 0.10$ & $3.23 \pm 0.07$ & $2.53 \pm 0.11$ & $7.45 \pm 0.31$ & $3.00 \pm 0.13$ & $5.13 \pm 0.17$ & \multicolumn{2}{|c|}{$0.79 \pm 0.05$} \\
\hline Asp & Glu & Ser & Gly & Pro & Arg & Ala & Tyr & Cys \\
\hline $8.79 \pm 0.22$ & $15.4 \pm 0.06$ & $5.87 \pm 0.27$ & $4.54 \pm 0.12$ & $0.82 \pm 0.09$ & $33.4 \pm 0.16$ & $11.8 \pm 0.15$ & $0.57 \pm 0.07$ & $15.5 \pm 0.16$ \\
\hline $\begin{array}{l}\text { alues are } n \\
\text { al - valine; } \\
\text { is - histidin } \\
\text { sp-aspar } \\
\text { o- tyrosin } \\
W-\text { dry we }\end{array}$ & $\begin{array}{l}\text { ans of th } \\
\text { et -meth } \\
\text { acid; Gl } \\
\text { Cys - cy }\end{array}$ & $\begin{array}{l}\text { determin } \\
\text { ne; Phe } \\
\text { glutamic } \\
\text { ne; }\end{array}$ & $\begin{array}{l}\text { is } \pm \text { sta } \\
\text { enylala } \\
\text {; Ser- }\end{array}$ & devia & $e ;$ & line; & & \\
\hline
\end{tabular}

Table 2

Fatty acid profile of $C$. disseminatus

\begin{tabular}{lc}
\hline Fatty acid & $\mathbf{( \% )}$ \\
\hline C6:0 & $2.6 \pm 0.01$ \\
C16:0 & $13.9 \pm 0.19$ \\
C16:1 & $1.85 \pm 0.04$ \\
C18:0 $18: 1 n 9 c$ & $3.56 \pm 0.02$ \\
C18:2n6c & $12.0 \pm 0.08$ \\
C22:6n3 & $56.6 \pm 0.26$ \\
\hline
\end{tabular}

Values are means of three determinations \pm standard deviation

C6:00 - caproic acid; C16:00 - palmitic acid; C16:01 - palmitoleic acid;

C18:00 - stearic acid; C18:1n9c-oleic acid; C18:2n6c - linoleic acid;

C22:6n3 - docosahexaenoic acid

Table 3.

Mineral composition of $C$. disseminatus

\begin{tabular}{ll}
\hline Macroelement $(\mathrm{mg} / \mathrm{g} \mathrm{DW})$ & \\
\hline $\mathrm{K}$ & $24.9 \pm 0.30$ \\
$\mathrm{Mg}$ & $6.72 \pm 0.02$ \\
$\mathrm{Ca}$ & $23.9 \pm 0.26$ \\
\hline Microelement $(\mu \mathrm{g} / \mathrm{g} \mathrm{DW})$ & \\
\hline $\mathrm{Cu}$ & $18.3 \pm 0.20$ \\
$\mathrm{Zn}$ & $193 \pm 0.74$ \\
$\mathrm{Mn}$ & $188 \pm 0.58$ \\
$\mathrm{Fe}$ & $5.98 \pm 0.01$
\end{tabular}

Values are means of three determinations \pm standard deviation DW-dry weight

Table 4.

Phenolic compounds profile of $C$. disseminatus

\begin{tabular}{lc}
\hline Flavones $(\mu \mathrm{g} / \mathrm{g} \mathrm{DW})$ & \\
\hline chrysoeriol & $0.3 \pm 0.02$ \\
luteolin7-O-glucoside & $0.6 \pm 0.001$ \\
apigenin7-O-glucoside & $0.2 \pm 0.001$ \\
\hline Biflavonoid $(\mu \mathrm{g} / \mathrm{g} \mathrm{DW})$ & $0.4 \pm 0.002$ \\
\hline amentoflavone & $9.46 \pm 0.2$ \\
\hline \multicolumn{2}{l}{ Hydroxybenzoic and hydroxycinnamic acid $(\mu \mathrm{g} / \mathrm{g} \mathrm{DW})$} \\
\hline$p$-hydroxybenzoic acid & $7.8 \pm 0.10$ \\
$p$-coumaric acid & $0.7 \pm 0.02$ \\
protocatechuic acid & $0.7 \pm 0.02$ \\
chlorogenic acid & \\
Values are means of three determinations \pm standard deviation \\
$D W-$ dry weight
\end{tabular}




\section{Macro- and microelements}

Mushrooms are a good source of minerals which are taken up from the substrate by the growing mycelium and translocated to the fruiting bodies. As in higher plants, the dominant mineral is potassium $(\mathrm{K})$, followed by phosphorus $(\mathrm{P})$, sodium $(\mathrm{Na})$, calcium (Ca), and magnesium (Mg) (Miles and Chang, 2004). Many mushroom species accumulate minor mineral elements e.g. trace elements to a considerably higher amounts than those in plants, such are copper $(\mathrm{Cu})$, zinc $(\mathrm{Zn})$, selenium $(\mathrm{Se})$, iron ( $\mathrm{Fe})$, and molybdenum (Mo), which are involved in many physiological processes (Zaidman et al., 2005). The most abundant macroelement in $C$. disseminatus was $\mathrm{K}$, followed by $\mathrm{Ca}$ and $\mathrm{Mg}$ (Table 3 ) and this finding is in accordance with the results of Heleno et al. (2015) who found $\mathrm{K}$ accounted for nearly $45 \%$ of the total mineral content in mushrooms.

Among microelements $\mathrm{Fe}$ was the most abundant element, followed by $\mathrm{Zn}, \mathrm{Mn}$ and $\mathrm{Cu}$ (Table 3). The higher content of elements such as $\mathrm{K}$ and $\mathrm{Fe}$ in $C$. disseminatus is probably the consequence of accumulation of these elements caused by the adaptation to environmental conditions since fungi absorb nutritive elements from the growing substrates (Kalač, 2013; Karaman and Matavulj, 2005).

\section{Phenolic profile}

Forty-five phenolic compounds were identified in methanolic extracts of $C$. disseminatus using LC-MS/MS technique, among which eight were identified and quantified as flavones (apigenin 7-O-glucoside, chrysoeriol, luteolin 7-O-glucoside), biflavonoid (amentoflavone), and hydroxybenzoic and hydroxycinnamic acids ( $p$-hydroxybenzoic acid, protocatechuic acid, $p$-coumaric acid, and chlorogenic acid) (Table 4).

$p$-Hydroxybenzoic acid was detected in higher amount in a wild growing $C$. Comatus $(61.53 \mu \mathrm{g} / \mathrm{g})$ originated from Portugal (Vaz et al., 2011) and C. micaceus $(25.06 \mu \mathrm{g} / \mathrm{g})$ from Poland (Nowacka et al., 2014), while fungal species $C$. comatus from Serbia had lower $p$-hydroxybenzoic acids content $(0.9 \mu \mathrm{g} / \mathrm{g})$ (Stojković et al., 2013) compared to our sample $(9.46 \mu \mathrm{g} / \mathrm{g})$ (Table 4). Furthermore, C. comatus from
Portugal was characterized by higher content of $p$-coumaric acid $(18.79 \mu \mathrm{g} / \mathrm{g})$ (Vaz et al., 2011), C. micaceus from Poland possessed lower content of the same compound $(5.96 \mu \mathrm{g} / \mathrm{g}$ ) (Nowacka et al., 2014), and the wild sample of $C$. comatus from Serbia showed the lowest amount $(1.5 \mu \mathrm{g} / \mathrm{g})$ of this phenolic compound (Stojković et al., 2013) in comparison to our result $(7.8 \mu \mathrm{g} / \mathrm{g})$ (Table 4$)$.

Phenolic compounds exhibit a wide range of physiological properties such as antiinflammatory, antimicrobial, cardioprotective, and vasodilatory effects, which have been related to their antioxidant activity (Alves et al., 2013; Ferreira et al., 2009). Antioxidant and antiproliferative activities of crude ethanolic and water extracts were previously determined for $C$. disseminatus by our research group and very strong and significant correlations $\left(r^{2}=0.99, p<0.01\right)$ between antiproliferative effect and total phenolic and total flavonoid content were found (Novaković et al., 2016).

\section{CONCLUSIONS}

According to the nutritional profile of fungal species Coprinellum disseminatus originnated from Serbia (proteins, amino acid composition, fatty acid profile, and mineral composition) and its phenolic profile this mushroom can be considered a functional food and can be used in a form of dietary supplement or spice in regular diet.

\section{ACKNOWLEDGEMENTS}

This paper is a result of the research within the project III 46021 financed by the Ministry of Education, Science and Technological Development, Republic of Serbia.

\section{REFERENCES}

1. Ackman, R.G. (1998). Remarks on official methods employing boron trifluoride in the preparation of methyl esters of the fatty acids of fish oils. Journal of the American Oil Chemists' Society, 75, 541-545

2. AOAC (1995). Official Methods of Analysis, $16^{\text {th }}$ Ed., Association of Official Analytical Chemists, Arlington VA, USA.

3. Appleton, J. (2002). Arginine: clinical potential of a semi-essential amino acid. (Arginine). Alternative Medicine Review, 7 (6), 512-523.

4. Ayaz, F.K.A., Chuang, L.T., Torun, H., Colak, A., Sesli, E., Presley, J., Smith, B. R., Glew, R. 
H. (2011). Fatty acid and amino acid compositions of selected wild-edible mushrooms consumed in Turkey. International Journal of Food Sciences and Nutrition, 62, 328-335.

5. Barros, L., Calhelha, R.C., Vaz, J.A., Ferreira, I.C., Baptista, P., Estevinho, L.M. (2007). Antimicrobial activity and bioactive compounds of Portuguese wild edible mushrooms methanolic extracts. European Food Research and Technology, 225, 151-156.

6. Belitz, H.D., Grosch, W. (1999). Amino acids, peptides and proteins. In Food Chemistry. Eds. H.-D. Belitz, W. Grosch, P. Schieberle, Springer-Verlag, Berlin, pp. 8-34.

7. Elisashvili, V. (2012). Submerged cultivation of medicinal mushrooms: bioprocesses and products. International Journal of Medicinal Mushrooms, 14, 211-239.

8. Ferreira, I.C., Barros, L., Abreu, R. (2009). Antioxidants in wild mushrooms. Current Medicinal Chemistry, 16, 1543-1560.

9. Ferreira, I.C., Vaz, J.A., Vasconcelos, M.H., Martins, A. (2010). Compounds from wild mushrooms with antitumor potential. Anti-Cancer Agents in Medicinal Chemistry, 10, 424436.

10. Folch, J., Lees, M., Sloane Stanley, G.H. (1957). A simple method for the isolation and purification of total lipids from animal tissues. Journal of Biological Chemistry, 226, 497-509.

11. Fountoulakis, M., Lahm, H.-W. (1998). Hydrolysis and amino acid composition analysis of proteins. Journal of Chromatography A, 826, 109-134

12. Gu, Y.H., Leonard, J. (2006). In vitro effects on proliferation, apoptosis and colony inhibition in ER-dependent and ER-independent human breast cancer cells by selected mushroom species. Oncology Reports, 15, 417-423.

13. Han, B., Toyomastu, T., Shinozawa, T. (1999). Induction of apoptosis by Coprinus disseminatus mycelial culture broth extract in human cervical carcinoma cells. Cell Structure and Function, 24, 209-215.

14. Heleno, S.A., Barros, L., Martins, A., Morales, P., Fernández-Ruiz, V., Glamoclija, J., Ferreira, I.C. (2015). Nutritional value, bioactive compounds, antimicrobial activity and bioaccessibility studies with wild edible mushrooms. LWT-Food Science and Technology, 63, 799-806.

15. Henderson, J.W., Brooks, A. (2010). Improved amino acid methods using Agilent ZORBAX Eclipse Plus C18 columns for a variety of Agilent LC instrumentation and separation goals. Agilent Technologies application note 59904547EN, USA.

16. Ivanova, T.S., Krupodorova, T.A., Barshteyn, V.Y., Artamonova, A.B., Shlyakhovenko, V.A. (2014). Anticancer substances of mushroom origin. Experimental Oncology, 36, 58-66.

17. Kalač, P. (2013). A review of chemical composition and nutritional value of wild-growing and cultivated mushrooms. Journal of the Science of Food and Agriculture, 93, 209-218.

18. Kalogeropoulos, N., Yanni, A.E., Koutrotsios, G., Aloupi, M. (2013). Bioactive microconsti- tuents and antioxidant properties of wild edible mushrooms from the island of Lesvos, Greece. Food and Chemical Toxicology, 55, 378-385.

19. Karaman, M.A., Matavulj, M.N. (2005). Macroelements and heavy metals in some lignicolous and tericolous fungi. Zbornik Matice srpske za prirodne nauke, 108, 255-267.

20. Karaman, M., Matavulj, M., Janjic, Lj. (2012). Antibacterial agents from lignicolous macrofungi. In Antimicrobial agents. Ed. V. Bobbarala, InTech, Rijeka, Croatia, pp. 361-386.

21. Karaman, M., Mimica Dukic, N., Knezevic, P., Svircev, Z., Matavuly, M. (2009). Antibacterial properties of selected lignicolous mushrooms and fungi from northern Serbia. International Journal of Medicinal Mushrooms, 11, 269-279.

22. Karaman, M., Stahl, M., Vulić, J., Vesić, M., Čanadanović Brunet, J. (2014). Wild-growing lignicolous mushroom species as sources of novel agents with antioxidative and antibacterial potentials. International Journal of Food Sciences and Nutrition, 65, 311-319.

23. Leal, A.R., Barros, L., Barreira, J.C., Sousa, M.J., Martins, A., Santos-Buelga, C., Ferreira, I.C. (2013). Portuguese wild mushrooms at the "pharma-nutrition" interface: Nutritional characterrization and antioxidant properties. Food Research International, 50, 1-9.

24. Meletis, C.D., Barker, J.E. (2005). Therapeutic uses of amino acids. Alternative and Complementary Therapies, 11, 24-28.

25. Miles, P.G., Chang, S.T. (2004). Mushrooms: Cultivation, Nutritional Value, Medicinal Effect, and Environmental Impact, CRC Press, Boca Raton.

26. Moradali, M.F., Mostafavi, H., Ghods, S., Hejaroude, G.A. (2008). Investigation of antimicrobial fatty acids from medicinal artist conk mushroom Ganoderma applanatum (Pers.) Pat. (Aphyllophoromycetideae) by TLC and spectroscopic detection. International Journal of Medicinal Mushrooms, 10, 149-154.

27. Ngai, P.H., Ng, T.B. (2003). Lentin, a novel and potent antifungal protein from shitake mushroom with inhibitory effects on activity of human immunodeficiency virus-1 reverse transcriptase and proliferation of leukemia cells. Life Sciences, 73, 3363-3374.

28. Novaković, A.R., Karaman, M.A., Kaišarević, S. N., Belović, M.M., Radusin, T.I., Beribaka, M.B., Ilić, N.M. (2016). Coprinellus disseminatus (Pers.) JE Lange 1938: In vitro antioxidant and antiproliferative effects. Food and Feed $R e$ search, 43, 93-101.

29. Novaković, A.R., Karaman, M.A., Matavulj, M. N., Pejin, B.M., Belović, M.M., Radusin, T.I., llić, N.M. (2015). An insight into in vitro bioactivity of wild-growing puffball species Lycoperdon perlatum (Pers) 1796. Food and Feed Research, 42, 51-58.

30. Nowacka, N., Nowak, R., Drozd, M., Olech, M., Los, R., Malm, A. (2014). Analysis of phenolic constituents, antiradical and antimicrobial activity of edible mushrooms growing wild in Poland. LWT-Food Science and Technology, 59, 689-694. 
31. Orčić, D., Francišković, M., Bekvalac, K., Svirčev, E., Beara, I., Lesjak, M., Mimica Dukić, N. (2014). Quantitative determination of plant phenolics in Urtica dioica extracts by highperformance liquid chromatography coupled with tandem mass spectrometric detection. Food Chemistry, 143, 48-53.

32. Puttaraju, N.G., Venkateshaiah, S.U., Dharmesh, S.M., Urs, S.M.N., Somasundaram, R. (2006). Antioxidant activity of indigenous edible mushrooms. Journal of Agricultural and Food Chemistry, 54, 9764-9772.

33. Redhead, S.A., Vilgalys, R., Moncalvo, J.M., Johnson, J., Hopple Jr, J.S. (2001). Coprinus Pers. and the disposition of Coprinus species sensu lato. Taxon, 203-241.

34. Ribeiro, B., de Pinho, P.G., Andrade, P.B., Baptista, P., Valentão, P. (2009). Fatty acid composition of wild edible mushrooms species: a comparative study. Microchemical Journal, 93, 29-35.

35. Rubio-Rodríguez, N., Beltrán, S., Jaime, I., Sara, M., Sanz, M.T., Carballido, J.R. (2010). Production of omega-3 polyunsaturated fatty acid concentrates: a review. Innovative Food Science and Emerging Technologies, 11, 1-12.

36. Shen, H.S., Shao, S., Chen, J.C., Zhou, T. (2017). Antimicrobials from mushrooms for assuring food safety. Comprehensive Reviews in Food Science and Food Safety, 16, 316-329.

37. Stojković, D., Reis, F.S., Barros, L., Glamočlija, J., Ćirić, A., van Griensven, L.J., Soković, M., Ferreira, I.C.F.R. (2013). Nutrients and nonnutrients composition and bioactivity of wild and cultivated Coprinus comatus (OF Müll.) Pers. Food and Chemical Toxicology, 59, 289-296.

38. Tidona, F., Sekse, C., Criscione, A., Jacobsen, M., Bordonaro, S., Marletta, D.,Vegarud, G.E. (2011). Antimicrobial effect of donkeys' milk digested in vitro with human gastrointestinal enzymes. International Dairy Journal, 21, 158165.

39. Torbica, A., Zivancev, D., Nikolic, Z., Đorđevic, V., Nikolovski, B. (2010). The advantages of lab-on-a-chip method in determination of Kunitz trypsin inhibitor in soybean varieties. Journal of
Agricultural and Food Chemistry, 58, 79807985.

40. Turkoglu, A., Duru, M.E., Mercan, N., Kivrak, I., Gezer, K. (2007). Antioxidant and antimicrobial activities of Laetiporus sulphureus (Bull.) Murrill. Food Chemistry, 101, 267-273.

41. Vaz, J.A., Almeida, G.M., Ferreira, I.C., Martins, A., Vasconcelos, M.H. (2012). Clitocybe alexandri extract induces cell cycle arrest and apoptosis in a lung cancer cell line: Identification of phenolic acids with cytotoxic potential. Food Chemistry, 132, 482-486.

42. Vaz, J.A., Barros, L., Martins, A., SantosBuelga, C., Vasconcelos, M.H., Ferreira, I.C. (2011). Chemical composition of wild edible mushrooms and antioxidant properties of their water soluble polysaccharidic and ethanolic fractions. Food Chemistry, 126, 610-616.

43. Wang, X-M., Zhang, J., Wu, L-H., Zhao, Y-L., Li, T., Li, J-Q., Wang, Y-Z., Liu, H-G. (2014). A mini-review of chemical composition and nutritional value of edible wild-grown mushroom from China. Food Chemistry, 151, 279-285.

44. Wasser, S. (2002). Medicinal mushrooms as a source of antitumor and immunomodulating polysaccharides. Applied Microbiology and Biotechnology, 60, 258-274.

45. Xu, X., Yan, H., Chen, J., Zhang, X. (2011). Bioactive proteins from mushrooms. Biotechnology Advances, 29, 667-674.

46. Yilmaz, N., Solmaz, M., Türkekul, İ., Elmastaş, M. (2006). Fatty acid composition in some wild edible mushrooms growing in the middle Black Sea region of Turkey. Food Chemistry, 99, 168-174.

47. Zaidman, B.Z., Yassin, M., Mahajna, J., Wasser, S.P. (2005). Medicinal mushroom modulators of molecular targets as cancer therapeutics. Applied Microbiology and Biotechnology, 67, 453-468.

48. Zhou, X., Gong, Z., Su, Y., Lin, J., Tang, K. (2009). Cordyceps fungi: natural products, pharmacological functions and developmental products. Journal of Pharmacy and Pharmacology, 61, 279-291. 


\title{
НУТРИТИВНИ И ФЕНОЛНИ ПРОФИЛ МАЛЕ ЈЕСТИВЕ ГЉИВЕ COPRINELLUS DISSEMINATUS (PERS.) J.E. LANGE 1938
}

\author{
Александра Р. Новаковић*1, Маја А. Караман ${ }^{2}$, Иван Љ. Миловановић ${ }^{1}$, Александра М. \\ Торбица ${ }^{1}$, Јелена М. Томић ${ }^{1}$, Борис М. Пејин ${ }^{3}$, Маријана Б. Сакач ${ }^{1}$ \\ ${ }^{1}$ Универзитет у Новом Саду, Научни институт за прехрамбене технологије у Новом Саду, 21000 \\ Нови Сад, Булевар цара Лазара бр. 1, Србија \\ ${ }^{2}$ Универзитет у Новом Саду, Департман за биологију и екологију, 21000 Нови Сад, Трг Доситеја \\ Обрадовића бр. 3, Србија \\ ${ }^{3}$ Универзитет у Београду, Департман за природне науке, Институт за мултидисциплинарна \\ истраживања,11030 Београд, Кнеза Вишеслава бр. 1, Србија
}

Сажетак: Циљ овога рада био је да се испита нутритивни профил мале јестиве гљиве Coprinellus disseminatus пореклом из Србије са акцентом на протеине, аминокиселине, масне киселине и минерални састав, као и да се одреди њен фенолни профил. Садржај укупних протеина анализиране гљиве износио је $9.72 \%$. Електрофорезом је идентификовано петнаест протеинских фрракција молекулских маса у распону од 1.6 до $63.6 \mathrm{kDa}$, при чему присуство протеинске фрракције молекулске масе $27.5 \mathrm{kDa}$ указује на могућу антифунгалну активност. Садржај укупних есенцијалних и неесенцијалних аминокиселина износио је 29.57 и $96.69 \mathrm{mg} / \mathrm{g}$ СМ, респективно. Најзаступљенија есенцијална аминокиселина је леуцин. Маснокиселинкси састав C. disseminatus одликују полинезасићене масне киселине (PUFA, 59.1\% од укупних масних киселина) које доминирају над засићеним (SFA, 23.1\% од укупних масних киселина) и мононезасићеним масним киселинама (MUFA, $17.9 \%$ од укупних масних киселина). Доминантне масне киселине су линолна (56.6\%), палмитинска (13.9\%) и олеинска киселина (12.0\%). C. Disseminatus је најбогатија калијумом, калцијумом и магнезијумом од макроелемената, док од микроелемента доминира гвожђе. У метанолном екстракту $C$. disseminatus квантификовано је осам фенолих једињења применом LC-MS/MS, при чему су највиши садржаји забележени за $p$ хидроксибензоеву киселину $(9.46 \pm 0.2 \mu \mathrm{g} / \mathrm{g} \mathrm{CM})$ и р-кумаринску киселину $(7.8 \pm 0.1 \mathrm{CM})$.

Кључне речи: гљива, протеини, аминокиселине, профол масних киселина, френолни профил, минерални састав

Received: 16 October 2018

Received in revised form: 21 November 2018

Accepted: 7 December 2018 